\title{
Production and characterisation of monoclonal antibodies to salmon pancreas disease virus
}

\author{
D. Todd ${ }^{1, *}$, V. A. Jewhurst ${ }^{2}$, M. D. Welsh ${ }^{2}$, B. J. Borghmans ${ }^{2}$, J. H. Weston ${ }^{2}$, \\ H. M. Rowley ${ }^{1}$, D. P. Mackie ${ }^{1}$, M. F. McLoughlin ${ }^{1}$
}

${ }^{1}$ Department of Agriculture and Rural Development for Northern Ireland (DARDNI) and ${ }^{2}$ Department of Veterinary Science, Queen's University of Belfast, Veterinary Sciences Division, Stormont, Belfast BT4 3SD, United Kingdom

\begin{abstract}
Six mouse monoclonal antibodies (mAbs) specific to salmon pancreas disease virus (SPDV) were produced following immunisation with purified virus preparations. These mAbs and $2 \mathrm{mAbs}$ resulting from an earlier investigation were characterised. None of the mAbs possessed virus neutralising activity but all reacted with 4 geographically different SPDV isolates as determined by indirect immunofluorescence. Three mAbs produced positive immunostaining with Western blots of SPDV proteins. The $4 \mathrm{H} 1 \mathrm{mAb}$ reacted with the $53 \mathrm{kDa}$ structural E1 glycoprotein present in virusinfected cells and in gradient-purified virus. Two mAbs, 5A5 and 7B2, which exhibited unusual immunofluorescence staining of the nuclear margin, reacted with a $35 \mathrm{kDa}$ protein, which is present in gradient-purified virus and which is considered to be the capsid protein. A sandwich ELISA, based on the use of mAb 2D9 for capture and a biotinylated conjugate of mAb 7A2 for detection, detected SPDV antigen in virus-infected Chinook salmon embryo-214 cells and gradient-purified virus. These mAbs may be of use in pathogenesis studies and in diagnostic test development.
\end{abstract}

KEY WORDS: Monoclonal antibody $\cdot$ Salmon pancreas disease virus $\cdot$ Salmonid alphavirus $\cdot$ Atlantic salmon

Resale or republication not permitted without written consent of the publisher

\section{INTRODUCTION}

Pancreas disease of farmed Atlantic salmon was first described in Scotland in 1984 (Munro et al. 1984) and has since been reported throughout Western Europe and in North America (Kent \& Elston 1987, Poppe et al. 1989). The disease causes major economic losses with up to $50 \%$ mortality in first year salmon smolts in Ireland (Wheatley 1994). Post-smolt salmon affected with pancreas disease appear runted, and histological lesions of the pancreas, heart and muscle are characteristic. The causal agent, named salmon pancreas disease virus (SPDV), was first isolated in our laboratory (Nelson et al. 1995). On the basis of sequence analysis of cDNA clones prepared using virus RNA, Weston et al. (1999) showed that SPDV is an alphavirus, the first

*E-mail: daniel.todd@dardni.gov.uk reported in fish. Sequence comparison of the structural protein region of the SPDV genome with that of rainbow trout sleeping disease virus (SDV) (Villoing et al. 2000) has shown that SPDV and SDV are very closely related. A recent study, reporting the biochemical characterisation of SPDV, described the identification of 2 major structural proteins as the E1 and E2 alphavirus glycoproteins (Welsh et al. 2000). This paper also described the production of 3 SPDV-specific monoclonal antibodies (mAbs), which were generated using a mouse tolerisation procedure; earlier attempts to immunise mice with unpurified virus failed to induce virus-specific antibody responses. Although these mAbs proved to be very useful for monitoring virus growth in cell culture and in the development of a method for purifying SPDV, it was recognised that additional antibody reagents would be required for pathogenesis studies and the development of diagnos- 
tic tests. We describe the characterisation of a new panel of SPDV-specific mAbs, which were produced by immunising mice with purified virus.

\section{MATERIALS AND METHODS}

Virus and cell culture. The F93-125 and F97-12 viruses were isolated in our laboratories from Irish and Scottish salmon, respectively (Nelson et al. 1995, Rowley et al. 1998). The N2P6 and N3P12 viruses, which were isolated from Norwegian salmon and trout, respectively, were supplied by Dr E. Christie, Intervet Norbio (Christie et al. 1998). Chinook salmon embryo (CHSE-214) cells were cultured in $75 \mathrm{~cm}^{2}$ flasks at $20^{\circ} \mathrm{C}$ in growth medium consisting of Eagle's minimum essential medium supplemented with $1 \%$ non-essential amino acids (Gibco), 0.01M HEPES buffer (Gibco),

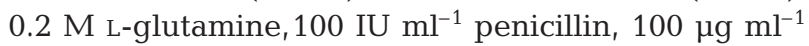
streptomycin and 10\% foetal calf serum (Gibco) (Nelson et al. 1995). For virus infection, monolayer cultures were grown to $80 \%$ confluence, medium was removed and cells were inoculated with $1 \mathrm{ml}$ virus to give a multiplicity of infection of approximately 1 TCID $_{50}$ cell ${ }^{-1}$. After adsorption for $1 \mathrm{~h}$ at $15^{\circ} \mathrm{C}, 14 \mathrm{ml}$ of maintenance medium (growth medium without foetal calf serum) was added to each flask. Infected cultures were incubated at $15^{\circ} \mathrm{C}$ for 7 to $8 \mathrm{~d}$, by which time virusinduced cytopathic effect had become evident (Welsh et al. 2000). For production of SPDV-infected CHSE214 cells on multiwell slides, cells in log-phase growth were resuspended in growth medium and infected with virus at approximately $1 \mathrm{TCID}_{50}$ cell $^{-1}$. Fifty microlitres of this suspension was placed in each well of the multiwell slides, which were then incubated at $15^{\circ} \mathrm{C}$ in a $5 \% \mathrm{CO}_{2}$ atmosphere in sealed boxes. Uninfected cell slides were similarly prepared. Slide cultures were harvested when a cytopathic effect was observed, usually after 3 to $4 \mathrm{~d}$, then washed in PBS and fixed in acetone.

Virus purification. SPDV was purified as described previously (Welsh et al. 2000). Briefly, this involved the precipitation of virus present in the supernatant from infected cells using polyethylene glycol and equilibrium density gradient centrifugation in sucrose (20 to $60 \%$ ) gradients. Sucrose fractions containing virus were identified by an immunodot blot assay using the SPDV-specific 2D9 mAb as described previously (Welsh et al. 2000). Briefly, this assay involved adsorbing proteins present in aliquots from sucrose gradient fractions onto nitrocellulose membranes and the subsequent detection of virus-specific antigen using mAb 2D9, followed by alkaline phosphatase conjugated goat anti-mouse-Ig (G $\alpha \mathrm{M}-\mathrm{AP})$ and enzyme substrate, 5-bromo-4-chloro-3-indolyl phosphate/nitro blue tetra- zolium (BCIP/NBT). In this earlier work, Welsh et al. (2000) reported that no reactivity was observed in this assay when preparations of uninfected cell proteins were tested. Highly purified virus was obtained by using 2 cycles of sucrose gradient centrifugation.

Preparation of SPDV antigens. For use in the indirect ELISA, SPDV virus, which had been precipitated with polyethylene glycol from $300 \mathrm{ml}$ supernatant from infected cells, was resuspended in approximately $1 \mathrm{ml}$ PBS. The suspension was treated with $0.154 \mathrm{ml}$ of $10 \%$ solution $N$-octyl $\beta$-D glucopyranoside (OG), rotated at room temperature for $1 \mathrm{~h}$ and centrifuged at $10000 \mathrm{~g}$ for $10 \mathrm{~min}$ in a microfuge. The supernatant was dialysed against excess PBS for $18 \mathrm{~h}$ at $4^{\circ} \mathrm{C}$ and protein content estimated by spectrophotometry at $280 \mathrm{~nm}$. For use in Western blotting, SPDV-infected CHSE-214 cells at $6 \mathrm{~d}$ post infection (p.i.) were briefly washed with ice-cold PBS, then scraped from the flask into icecold PBS and collected by centrifugation at $10000 \mathrm{~g}$ for 2 min in a microfuge. The supernatant was removed and the pellets pooled and resuspended in 1/60 original volume ice-cold PBS before storage at $-20^{\circ} \mathrm{C}$. Control antigens for use in ELISA and Western blotting were similarly prepared from uninfected cells. To compensate for the cells lysed by virus infection, the supernatant from uninfected CHSE-214 cells was combined with uninfected cells that were harvested from $25 \%$ of the flasks and that had been disrupted by freezing and thawing.

Mouse immunisation and $\mathbf{m A b}$ production. An aliquot of the peak virus fraction from the second sucrose-gradient virus purification, containing $0.2 \mathrm{mg}$ $\mathrm{ml}^{-1}$ protein, was prepared for inoculation by mixing 1:2 with Quil-A adjuvant. Three 12-wk-old BALB/C Fx1 female mice were each inoculated subcutaneously with $40 \mu \mathrm{g}$ of this virus protein. Booster immunisations were given after $3 \mathrm{wk}$ (40 $\mu \mathrm{g}$ virus protein in Quil-A subcutaneously) and $8 \mathrm{wk}$ (80 $\mu \mathrm{g}$ virus protein in PBS intraperitoneally). A final pre-fusion boost of $70 \mu \mathrm{g}$ virus protein in PBS was given intraperitoneally to 1 mouse after $15 \mathrm{wk}$.

Ten weeks after primary inoculation, test-bleed sera were assayed by indirect immunofluorescence (IIF) for SPDV antibodies. The mouse producing antibody of the highest titre was boosted at 15 wk followed $72 \mathrm{~h}$ later by serum harvest and spleen removal for fusion (F197) with NSO myeloma cells for hybridoma production. Hybridomas were cloned by 2 cycles at limiting dilution and ascites was produced as described previously (McHugh et al. 1988). Mouse ascites was partially-purified by ammonium sulphate precipitation as previously described (McNulty \& Allan 1984).

Isotyping of mAbs. mAb isotyping was carried out on selected second clone supernatants using a selfindicating dipstick kit (Sigma). 
Immunofluorescence. An IIF screen for the detection of SPDV-specific immunoglobulins was carried out using acetone-fixed SPDV-infected and uninfected CHSE-214 cells grown on multiwell slides. Hybridoma culture and clone supernatants were tested neat; ascites and ammonium sulphate precipitates were titrated in PBS. A previously produced SPDV-specific mAb 2D9 (Welsh et al. 2000) was used as a positive control. Fixed cells were incubated with test samples followed by a polyvalent goat-anti-mouse fluorescein isothiocyanate conjugate with specificity for IgG, IgA and $\operatorname{IgM}$ (Sigma). Incubations were for $1 \mathrm{~h}$ at $37^{\circ} \mathrm{C}$ in a moist chamber, with a 10 min wash in PBS after each. Slides were mounted in Citifluor and examined by UV microscopy. The reactivities of SPDV-specific mAbs with different SPDV isolates were determined by titrating each $\mathrm{mAb}$ by doubling dilution in PBS from a starting concentration of $10 \mu \mathrm{g}$ immunoglobulin $\mathrm{ml}^{-1}$, the end-point being taken as the last dilution at which a clearly positive cell could be identified.

Virus neutralisation test. mAbs were tested at a 1:20 starting dilution of ascites. One hundred microlitres of $\operatorname{SPDV}\left(200 \mathrm{TCID}_{50}\right.$ per $\left.100 \mu \mathrm{l}\right)$ was added to $100 \mu \mathrm{l}$ of 2-fold dilutions of $\mathrm{mAb}$ and incubated at $15^{\circ} \mathrm{C}$ for $1 \mathrm{~h}$. The mixtures were then inoculated into CHSE-214 cells in 24-well plates, $100 \mu \mathrm{l}$ per well, and allowed to adsorb for $1 \mathrm{~h}$ at at $15^{\circ} \mathrm{C}$. Following addition of $1 \mathrm{ml}$ maintenance medium with $2 \%$ foetal calf serum, cells were incubated at $15^{\circ} \mathrm{C}$ for $8 \mathrm{~d}$. The cultures were examined microscopically on alternate days for evidence of a cytopathic effect (Nelson et al. 1995).

SDS-PAGE. Proteins present in various forms of SPDV antigen and control uninfected cell antigen were analysed by SDS-PAGE (Laemmli 1970) on either a Bio-Rad Protean-II or mini-Protean-II gel apparatus with $10 \%$ resolving and $5 \%$ stacking gels. Samples were incubated for $3 \mathrm{~min}$ in gel-loading buffer $(0.15 \mathrm{M}$ Tris- $\mathrm{HCl} \mathrm{pH} 6.7,6 \%$ w/v SDS, $15 \% \quad \beta$-mercaptoethanol, $30 \%$ glycerol, bromophenol-blue to colour) before running on gel. Gels were stained with Coomassie brilliant blue, silver stained or used for Western blotting.

Western blotting. Nitrocellulose membrane $(0.45 \mu \mathrm{m}$ pore Bio-Rad) was pre-soaked in blot buffer $(0.048 \mathrm{M}$ tris, $0.039 \mathrm{M}$ glycine, $0.037 \% \mathrm{w} / \mathrm{v}$ SDS, $20 \% \mathrm{v} / \mathrm{v}$ methanol). Proteins from SPDV or control antigen preparations that had been fractionated by SDS-PAGE were blotted at $30 \mathrm{~V}$ overnight in a Bio-Rad Trans-Blot wet cell or at $15 \mathrm{~V}$ for $45 \mathrm{~min}$ in a semi-dry apparatus (Bio-Rad Trans-Blot SD). Blots were rinsed in distilled water and air dried before blocking with $3 \%$ gelatin in TBS for $30 \mathrm{~min}$. Where necessary, blots were cut into $4 \mathrm{~mm}$ wide strips. Proteins were detected with mAbs or with a rabbit polyclonal antiserum raised against the E2 protein of SDV and supplied by Dr M. Brémont
(Unité Virologie et Immunologie Moléculaires, INRA, Jouy-en-Josas, France) and visualised using either GoM-AP or alkaline phosphatase conjugated anti-rabbit and BCIP/NBT. All incubations and washes were as previously described for immunodot-blots (Welsh et al. 2000).

Biotinylation of $\mathbf{m A b}$. The SPDV-specific mAb 7A2 was biotinylated using sulfosuccinimidyl-6 (biotinamido)-hexanoate (Sulfo-NHS-LC-Biotin) from a biotinylation kit (Pierce). Two micrograms mAb 7A2 immunoglobulin, prepared by ammonium sulphate precipitation of mouse ascites fluid, was added to PBS to give a protein concentration of $1.3 \times 10^{-5} \mathrm{mM}$. Biotin solution was added, to a final biotin concentration of $2.7 \times 10^{-4} \mathrm{mM}$. This gave $\times 20$ excess biotin. Solution was incubated on a rocker at room temp for $30 \mathrm{~min}$ then dialysed against excess PBS for $60 \mathrm{~h}$ at $4^{\circ} \mathrm{C}$, and protein content was estimated by spectrophotometry at $280 \mathrm{~nm}$.

Indirect ELISA. Those mAbs that had the ability to detect SPDV antigen by ELISA were identified using an indirect format, which comprised 4 addition and incubation steps, each followed by thorough washing with PBS containing $0.05 \%$ Tween-20 (PBS-T), before addition of substrate: (1) plates were coated overnight at $4{ }^{\circ} \mathrm{C}$ with $100 \mu \mathrm{l}$ well ${ }^{-1}$ OG-treated SPDV antigen or OG-treated control uninfected cell antigen at $20 \mu \mathrm{g}$ $\mathrm{ml}^{-1}$, diluted in bicarbonate coating buffer, $\mathrm{pH} 9.6$; (2) $200 \mu \mathrm{l}$ well $^{-1}$ blocking solution, PBS containing $4 \%$ BSA, was incubated for $1 \mathrm{~h}$ at $37^{\circ} \mathrm{C}_{i}$ (3) $\mathrm{mAb}(\mathrm{s})$ under test, $100 \mu \mathrm{l} \mathrm{well}{ }^{-1}$, were incubated for $1 \mathrm{~h}$ at $37^{\circ} \mathrm{C}_{i}$ hybridoma culture and clone supernatants were tested neat, ascites and ammonium sulphate precipitates were titrated in PBS-T containing 1\%BSA; and (4) $100 \mu \mathrm{l}$ well ${ }^{-1}$ of a 1:4000 dilution goat-anti-mouse IgG horseradish-peroxidase conjugate (Sigma) was incubated for $1 \mathrm{~h}$ at $37^{\circ} \mathrm{C}$. The enzyme substrate tetramethyl benzidine (Chemicon) was then added, $100 \mu \mathrm{lwell}^{-1}$, and incubated for $10 \mathrm{~min}$ at room temperature before stopping the reaction with $50 \mu \mathrm{l}$ well ${ }^{-1} 1 \mathrm{M} \mathrm{H}_{2} \mathrm{SO}_{4}$. Absorbance at $450 \mathrm{~nm}$ was read using a Titertek Multiscan.

Sandwich ELISA. Sandwich ELISA format was used to identify mAbs that, when used to coat plastic microtitre plates, had the ability to capture SPDV antigen that could subsequently be detected with the biotinylated mAb $7 \mathrm{~A} 2$. It comprised 5 addition and incubation steps, each followed by thorough washing with PBS-T, before addition of substrate as above: (1) plates were coated overnight at $4^{\circ} \mathrm{C}$ with $100 \mu \mathrm{l}$ well ${ }^{-1} \mathrm{mAb}$ under test (ascites immunoglobulin precipitated with $\left[\mathrm{NH}_{4}\right]_{2} \mathrm{SO}_{4}$ ), titrated in bicarbonate coating buffer, pH 9.6; (2) SPDV antigen or control uninfected cell antigen, $100 \mu \mathrm{l}$ well $^{-1}$, diluted in PBS containing $0.1 \% \mathrm{OG}$, was incubated for $2 \mathrm{~h}$ at $37^{\circ} \mathrm{C}_{i}$ (3) $200 \mu \mathrm{l}$ 
well ${ }^{-1}$ blocking solution, PBS containing $4 \%$ BSA, was incubated for $1 \mathrm{~h}$ at $37^{\circ} \mathrm{C}_{i}$ (4) $100 \mu \mathrm{l}$ well ${ }^{-1}$ biotinylated $7 \mathrm{~A} 2 \mathrm{mAb}, 1 \mu \mathrm{g} \mathrm{ml}^{-1}$, diluted in PBS-T containing $1 \%$ BSA was incubated for $1 \mathrm{~h}$ at $37^{\circ} \mathrm{C}_{i}$ and (5) $100 \mu \mathrm{lwell}^{-1}$ of a 1:4000 dilution streptavidin horseradish-peroxidase conjugate (Zymed) was incubated for $45 \mathrm{~min}$ at $37^{\circ} \mathrm{C}$. Arising from this study, an antigen-detecting ELISA was developed using the sandwich format, in which the SPDV-specific mAb 2D9 was used for capturing purposes.

\section{RESULTS}

\section{Production of SPDV-specific mAbs}

Serum collected from the mouse used for mAb production contained SPDV-specific antibodies at a titre of 1:3200 as determined by IIF. Of 614 hybridoma culture supernatants resulting from the fusion (F197) and initially tested by IIF, 35 exhibited definite positive or suspect positive staining and were selected for storage. Nine hybridoma cultures were selected for cloning by 2 cycles of limiting dilution on the basis of their IIF reactivity and indirect ELISA potential. Two hybridoma cultures yielded no positive clones and, of the remaining 7, 1 clone from each was selected for second cloning. Following IIF screening, 1 each of the second clones was used for ascites production. These were designated mAbs 4H1, 5A5,5D1, 6E1, 7A2, 7B2 and $7 \mathrm{C} 12$. Ascites produced using mAb 6E1 did not contain SPDV-specific antibody as determined by IIF and was discounted for characterisation purposes.

\section{Immunofluorescence and virus-neutralising reactivities of SPDV-specific mAbs}

Data concerning the 6 mAbs from F197 and 2 mAbs, produced previously using the mouse tolerisation procedure (F180; Welsh et al. 2000) are shown in Table 1. Four of the $8 \mathrm{mAbs}$ were of the G1 isotype, but isotypes G2a, G2b and M were also represented. None of the mAbs possessed virus neutralising activity. The IIF staining patterns exhibited by the mAbs were investigated using dilutions of ascites fluid or using immunoglobulin solutions prepared from ascites by ammonium sulphate precipitation. With each $\mathrm{mAb}$, antigen staining was confined to cells present in virus-infected cultures; no staining was observed in non-infected CHSE214 cells. The IIF titres determined for neat ascites fluid ranged from 1:3000 to 1:32 000. Although each of the $8 \mathrm{mAbs}$ produced staining of virus antigen present in the cytoplasm, mAbs $5 \mathrm{~A} 5$ and $7 \mathrm{~B} 2$ produced a distinctive staining pattern, characterised by intense
Table 1. Isotype and reactivities of salmon pancrease disease virus-specific monoclonal antibodies (mAbs). IF: Immunofluorescence; IIF: Indirect immunofluorescence. None of the mAbs exhibited virus neutralising activity

\begin{tabular}{|c|c|c|c|}
\hline $\begin{array}{l}\text { Fusion / } \\
\text { mAb }\end{array}$ & Isotype & $\begin{array}{l}\text { Reciprocal } \\
\text { IIF titre }\end{array}$ & IF staining \\
\hline F180 / 2D9 & G1 & $16 \mathrm{~K}$ & Cytoplasm \\
\hline F180 / 5D3 & G1 & $4 \mathrm{~K}$ & Cytoplasm \\
\hline F197 / 4H1 & G2a & $32 \mathrm{~K}$ & Cytoplasm \\
\hline F197 / 5A5 & G1 & $32 \mathrm{~K}$ & $\begin{array}{l}\text { Nuclear margin } \\
\& \text { cytoplasm }\end{array}$ \\
\hline F197 / 5D1 & M & $16 \mathrm{~K}$ & Cytoplasm \\
\hline F197 / 7A2 & G1 & $32 \mathrm{~K}$ & Cytoplasm \\
\hline F197 / 7B2 & G2b & $3 \mathrm{~K}$ & $\begin{array}{l}\text { Nuclear margin } \\
\& \text { cytoplasm }\end{array}$ \\
\hline F197 / 7C12 & G2a & $4 \mathrm{~K}$ & Cytoplasm \\
\hline
\end{tabular}

staining at the margin of the nucleus. This was particularly evident at earlier times p.i. (Day 3) and when higher mAb concentrations were used (Fig. 1a).

The IIF staining patterns exhibited by the 6 remaining $\mathrm{mAbs}$ depended on the time p.i. and reflected the cellular changes resulting from infection. Thus, at early times p.i. (Days 2 and 3), intense staining of an area close to the nucleus was prominent in some infected cells (not shown) when mAbs 2D9, 5D3, 4H1 and $7 \mathrm{~A} 2$ were used. Cytoplasmic staining at Day 5 p.i. was generally uniform and finger-like projections were commonly observed (Fig. 1b). At later times p.i. (Day 7), a proportion of the infected cells showed a typical SPDV cytopathic effect, with virus antigen staining intensely (Fig. 1c). Using IIF performed with the 2D9 $\mathrm{mAb}$ and following infection at a multiplicity of infection of approximately 1 , small numbers of virusinfected cells exhibiting weak staining were detected at Day 2 p.i. The numbers of infected cells and the intensity of staining increased, and positive staining was readily detectable at Days 3 and 4 p.i.

All 8 mAbs reacted with each of the 4 geographically different SPDV isolates (Table 2). Differences in the titration end-points were generally small (2- or 4 -fold). However, the 8-fold difference observed between the titres of the $5 \mathrm{D} 1 \mathrm{mAb}$ required to produce staining of the Scottish and Irish SPDV isolates was noted.

\section{Western blotting reactivities of SPDV-specific mAbs}

Immunoblotting, performed with proteins from virusinfected cells and gradient-purified virus was used to identify the proteins with which the SPDV-specific mAbs react. Specific reactions were detected with 3 of the $8 \mathrm{mAbs}$. The $4 \mathrm{H} 1 \mathrm{mAb}$ reacted positively with a $53 \mathrm{kDa}$ protein that was present in virus-infected cells 

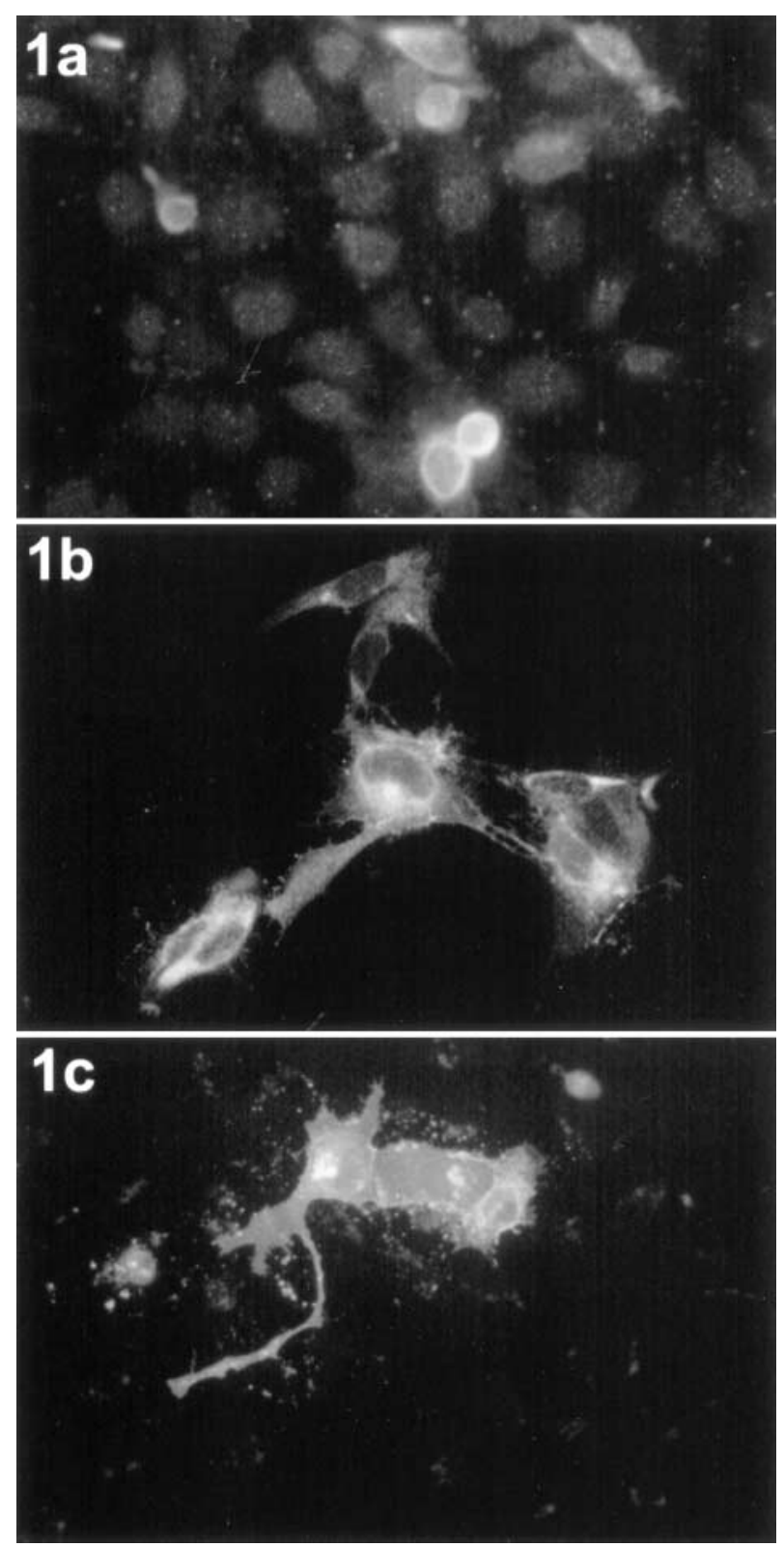

Fig. 1. Indirect immunofluorescence staining of salmon pancreas disease virus (SPDV)-infected Chinook salmon embryo214 cells with virus-specific monoclonal antibodies (mAbs). (a) With mAb 5A5 at Day 5 post infection, showing staining of nuclear margin. (b) With mAb $4 \mathrm{H} 1$ at Day 5 post infection showing typical cytoplasmic staining. Note intense staining of small area close to nucleus of central cell, presumed to correspond to glycoprotein trafficking through the Golgi apparatus. (c) With mAb 7A2 at Day 7 post infection showing staining of infected cells exhibiting cytopathic effect

and that was absent from uninfected cells used for control purposes (Fig. 2a). Weaker staining reactions were observed with other proteins present in virus-infected cells and these were considered likely to be due to secondary antibody cross-reactions or non-specific reac-
Table 2. Reactivities of SPDV-specific mAbs with geographically different isolates. See Table 1 for abbreviations

\begin{tabular}{|c|c|c|c|c|}
\hline \multirow{2}{*}{ Fusion / mAb } & \multicolumn{4}{|c|}{ Reciprocal IIF titre } \\
\hline & $\begin{array}{l}\text { Irish } \\
\text { salmon }\end{array}$ & $\begin{array}{l}\text { Norwegian } \\
\text { salmon }\end{array}$ & $\begin{array}{l}\text { Norwegian } \\
\text { trout }\end{array}$ & $\begin{array}{l}\text { Scottish } \\
\text { salmon }\end{array}$ \\
\hline F180 / 2D9 & 128 & 128 & 256 & 128 \\
\hline F180 / 5D3 & 16 & 16 & 32 & 32 \\
\hline F197 / 4H1 & 32 & 16 & 32 & 16 \\
\hline F197 / 7A2 & 128 & 128 & 64 & 128 \\
\hline F197 / 7C12 & 4 & 8 & 2 & 2 \\
\hline F197 / 7B2 & 32 & 16 & 32 & 8 \\
\hline F197 / 5A5 & 32 & 32 & 32 & 16 \\
\hline F197 / 5D1 & 8 & 4 & 4 & 1 \\
\hline
\end{tabular}

tions, in that some of these were also evident when proteins from uninfected cells were immunoblotted. Weakly staining bands with mobilities less than that of the $53 \mathrm{kDa}$ protein may have been uncleaved, virusspecific precursor proteins. With proteins from infected cells, the $5 \mathrm{~A} 5$ and $7 \mathrm{~B} 2 \mathrm{mAbs}$ both produced strong immunoblotting reactions with a $35 \mathrm{kDa}$ protein and weaker reactions with a $30 \mathrm{kDa}$ protein. These positively reacting proteins were not present in uninfected CHSE-214 cells (Fig. 2b). The 7A2 mAb produced a positive reaction with a 65 to $70 \mathrm{kDa}$ protein that was present in virus-infected cells. However, since a protein band of this size from uninfected cells also exhibited immunostaining and since high concentrations of $\mathrm{mAb} 7 \mathrm{~A} 2$ were required to effect these reactions in comparison with the concentrations required for the $4 \mathrm{H} 1,5 \mathrm{~A} 5$ and $7 \mathrm{~B} 2 \mathrm{mAbs}$, the $7 \mathrm{~A} 2 \mathrm{mAb}$ reaction was considered to be non-specific (result not shown). No reactions were obtained when the enzyme-labelled anti-mouse or anti-rabbit immunoglobulin conjugates were used alone; that is, in the absence of the primary $\mathrm{mAb}$ or rabbit antiserum reagents.

With proteins comprising preparations of gradientpurified virus, the $4 \mathrm{H} 1 \mathrm{mAb}$ again reacted strongly with a protein, sized at $53 \mathrm{kDa}$ (Fig. 2c). The rabbitanti-SDV E2 antiserum produced a positive reaction with a faster-migrating protein, which was estimated to be approximately $47 \mathrm{kDa}$ (Fig. 2c). A protein of approximately $35 \mathrm{kDa}$ was found to be reactive with the 5A5 and 7B2 mAbs (Fig. 2c).

\section{Reactivities of SPDV-specific mAbs in ELISAs}

The potential of the SPDV-specific mAbs to function as reagents in antigen-detecting ELISAs was investigated. Firstly, an indirect ELISA format was used to assess the abilities of the mAbs to react with OGtreated SPDV antigen, which had been adsorbed to microtitre plates. Only mAb $7 A 2$ generated ELISA 
Table 3. Summary of ELISA capabilities of SPDV-specific mAbs. *N-octyl $\beta$-D glucopyranoside-treated SPDV antigen (Virus Ag) or control uninfected cell antigen (Con Ag), adsorbed to plate, detected by test mAb using indirect ELISA format; ${ }^{* *}$ Biotinylated $7 \mathrm{~A} 2 \mathrm{mAb}$ used to detect SPDV antigen or control uninfected cell antigen that had been captured firstly by test $\mathrm{mAb}$ in a Sandwich ELISA format

\begin{tabular}{|c|c|c|c|c|}
\hline \multirow[t]{2}{*}{$\begin{array}{l}\text { Fusion / } \\
\text { mAb }\end{array}$} & \multicolumn{2}{|c|}{$\begin{array}{l}\text { ELISA detector ability* } \\
\text { Absorbance at } 450 \mathrm{~nm}\end{array}$} & \multicolumn{2}{|c|}{$\begin{array}{l}\text { ELISA capture ability }{ }^{* *} \\
\text { Absorbance at } 450 \mathrm{~nm}^{*}\end{array}$} \\
\hline & Virus Ag & Con Ag & Virus Ag & Con Ag \\
\hline F180 / 2D9 & 0.1 & 0.1 & 1.0 & 0.1 \\
\hline F180 / 5D3 & 0.1 & 0.1 & 0.2 & 0.1 \\
\hline F197 / 4H1 & 0.2 & 0.1 & 0.2 & 0.1 \\
\hline F197 / 5A5 & 0.1 & 0.1 & 0.1 & 0.1 \\
\hline F197 / 7A2 & 0.8 & 0.1 & 0.3 & 0.1 \\
\hline F197 / 7B2 & 0.1 & 0.1 & 0.1 & 0.1 \\
\hline F197 / 7C12 & 0.1 & 0.1 & 0.1 & 0.1 \\
\hline
\end{tabular}

absorbance values that were substantially above the absorbance produced using control uninfected cell antigen (Table 3), and this mAb, as a biotinylated conjugate, was selected for use as the antigen-detecting reagent in the sandwich ELISA format. The 5D1 mAb was not assessed for antigen-detecting capability since, with an $\mathrm{M}$ isotype, it did not react with the IgGdetecting enzyme conjugate.

In the second part of this investigation, the abilities of the 8 SPDV-specific mAbs to capture virus antigen, which subsequently could be detected by the biotinylated mAb 7A2, was assessed using the antigendetecting sandwich ELISA format. Only mAb 2D9 exhibited high levels of capture ability under these conditions, although mAbs 5D3, 4H1 and 7A2 exhibited low levels (Table 3). Relatively low absorbance values ( 0.1 optical density unit) were generated when control uninfected cell antigen was used for capture by the mAbs tested. The sandwich ELISA based on mAb 2D9 for capture and the biotinylated 7A2 mAb for detector was capable of detecting virus antigen in frozen and thawed lysates of CHSE-214 cells, which had been infected at a multiplicity of infection of 1 , on Day 3 p.i. and under similar conditions of infection, infected cell lysates collected at Day 7 or 8 p.i. produced positive ELISA responses at end-point dilutions of 1:128 (results not shown). This ELISA was capable of detecting SPDV particles purified by sucrose density gradient fractionation. As shown in Fig. 3, the gradient fractions displaying peak ELISA reactivity corresponded to those producing the most intense reactions in the immunodot blot assay. This result indicated that the sandwich ELISA detects a protein component of virus particles.

\section{DISCUSSION}

Earlier attempts to produce SPDV-specific antibody reagents for research and diagnostic purposes met with limited success. Immunisation of rabbits and mice with high levels of infectious virus, obtained by differential ultracentrifugation, failed to elicit antiviral antibody responses as determined by IIF and virus neutral-
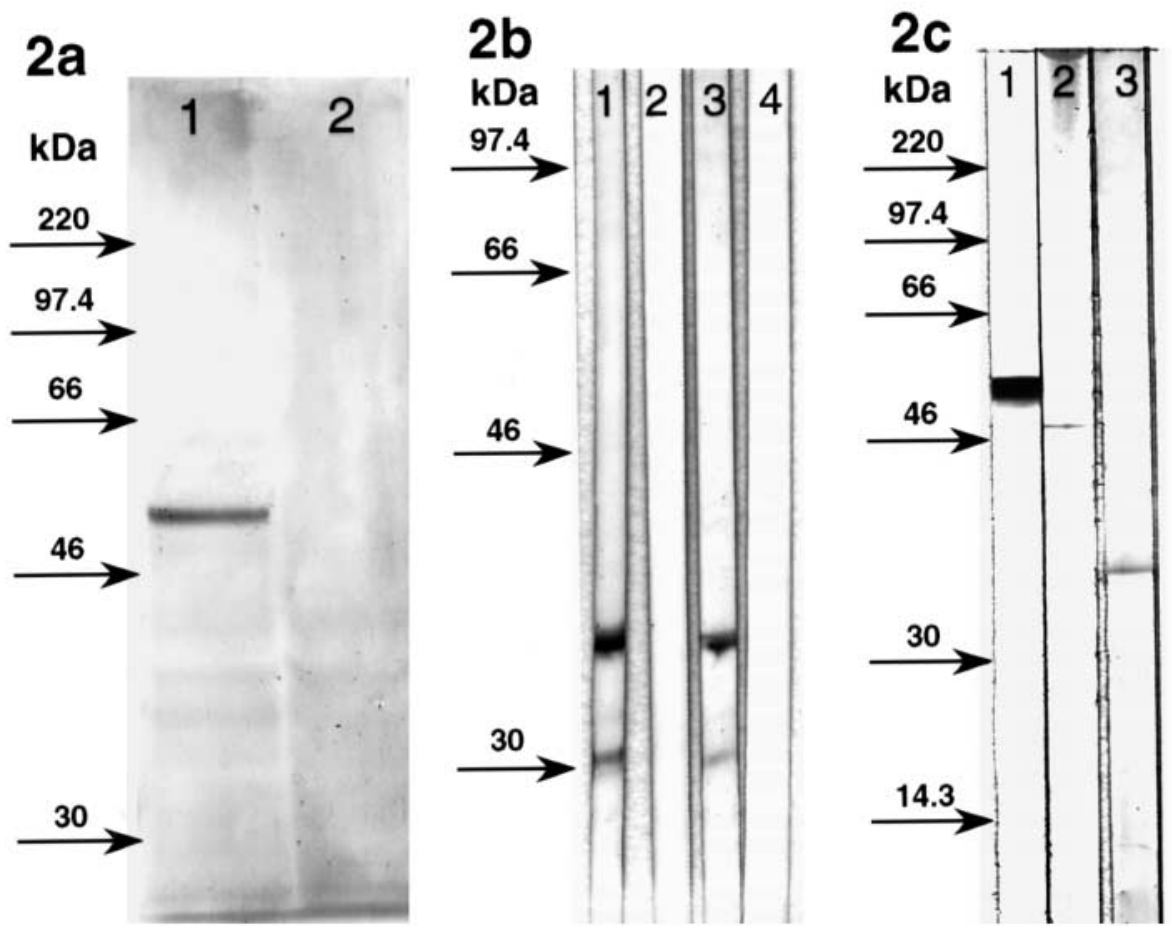

Fig. 2. Western blot analyses of SPDV proteins with virus-specific mAbs. (a) With mAb $4 \mathrm{H} 1$ using proteins from virusinfected cells (lane 1) and uninfected cells (lane 2). Note positive reaction with $53 \mathrm{kDa}$ protein. (b) With mAbs 5A5 and $7 \mathrm{~B} 2$ using proteins from virusinfected cells (lane 1, mAb 5A5; lane $3 \mathrm{mAb}$ 7B2) and uninfected cells (lane 2, mAb 5A5; lane 4, $\mathrm{mAb}$ 7B2). Note strong positive reactions with $35 \mathrm{kDa}$ protein and weaker positive reactions with $30 \mathrm{kDa}$ protein. (c) With mAbs 4H1 (lane 1), mAb 5A5 (lane 3) and rabbit anti-sleeping disease virus (SDV) E2 antiserum (lane 2) using proteins from gradient-purified virus. Note positive reactions with a $53 \mathrm{kDa}$ protein using mAb $4 \mathrm{H} 1$, a $47 \mathrm{kDa}$ protein using the rabbit anti-SDV E2 antiserum and a $35 \mathrm{kDa}$ protein using mAb 5A5 
a.
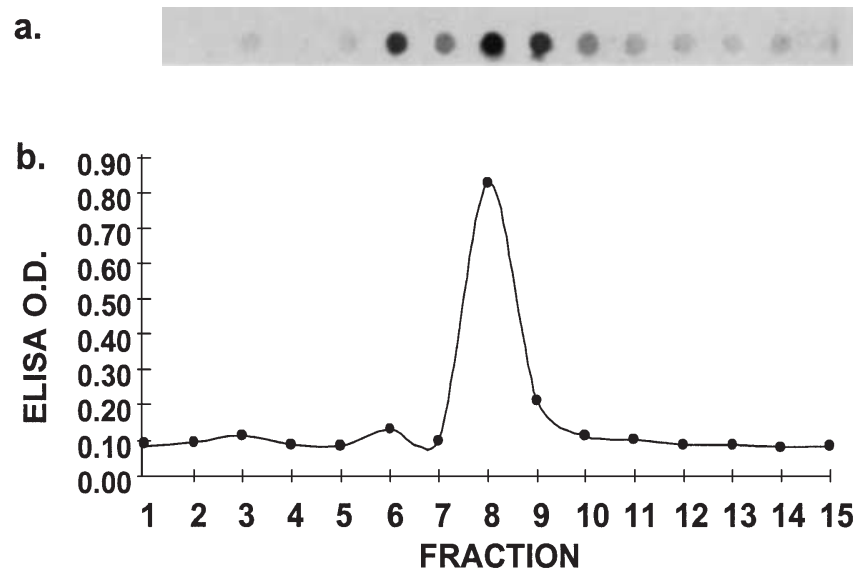

Fig. 3. Detection of SPDV following sucrose density gradient fractionation using (a) immunodot blot assay and (b) antigendetecting sandwich ELISA. O.D.: Optical density units

isation tests (unpubl. results) and suggested that, in the presence of contaminating cellular proteins, SPDV is poorly immunogenic. Welsh et al. (2000) overcame this problem by using a mouse tolerisation procedure and succeeded in producing 3 mAbs, designated 2D9, 5D3 and 1A9. Until now, these have remained largely uncharacterised. In the present study, preparations of purified virus have been used to immunise mice to produce additional SPDV-specific mAbs.

On the basis of our previous experience in producing mAbs to a wide range of other animal viruses, the proportion $(5.7 \%)$ of virus-specific hybridomas as determined by IIF was considered to be low and provided a further indication that SPDV is a poor immunogen in mice. Nonetheless, 8 mAbs, including 2 (2D9 and 5D3) generated previously (Welsh et al. 2000), were selected for characterisation following production as ascites fluid. IIF showed that all $8 \mathrm{mAbs}$ were reactive with each of 4 geographically different SPDV isolates, a finding that suggests that antigenic variation may be small and that, if employed as diagnostic reagents, these antibodies may find widespread use. The 8 -fold difference between the antibody dilutions required to produce positive staining with the Irish and Scottish SPDV isolates indicated that there may be a small difference in the amino acid sequence(s) comprising the epitope with which mAb 5D1 reacts.

The ability of SPDV mAbs to readily detect virusinfected cells at early times p.i. may, in the future, allow the virus neutralisation test to be improved. The currently used virus neutralisation test depends on the detection at Day 8 p.i. of a virus-induced cytopathic effect, which is difficult to read and requires input from an experienced fish virologist. The ability to specifically immunostain virus antigen at Day 3 or 4 p.i. will reduce the time needed to complete the test and will avoid the need to identify a cytopathic effect, thus improving test accuracy.

In this study the protein specificity of each mAb was investigated using Western blotting, performed with proteins derived from virus-infected cells and gradient-purified virus. Results indicated that the 4H1, 5A5 and 7B2 mAbs produced virus-specific positive reactions with blotted proteins, suggesting that the epitopes with which they react are linear or continuous. Since such epitopes are more likely to withstand the denaturation associated with formalin fixation, these mAbs may be especially suited as immunohistochemical reagents. On the basis of the size of the reactive protein and its presence in purified virus samples, it is probable that the $5 \mathrm{~A} 5$ and $7 \mathrm{~B} 2 \mathrm{mAbs}$ are specific to the SPDV capsid protein. The estimated size of the reactive protein, $35 \mathrm{kDa}$, is close to that ( $36 \mathrm{kDa}$ ) which can be predicted from sequence analysis (Weston et al. 1999). This is the first experimental relative molecular weight $\left(M_{\mathrm{r}}\right)$ estimate for the SPDV capsid protein, since an earlier study involving silver staining of SDSPAGE profiles, which had revealed the presence of the 2 SPDV glycoproteins, E1 and E2, in purified virus preparations, failed to show the presence of the capsid protein (Welsh et al. 2000). It is likely that the additional sensitivity conferred by immunoblotting allowed the capsid protein to be identified. When infected cell protein preparations were used for immunoblotting, an additional $30 \mathrm{kDa}$ protein band was found to react weakly with the $5 \mathrm{~A} 5$ and 7B2 mAbs. The absence of this band in uninfected cells suggested that it is virusspecific, probably a cleavage product derived from the capsid protein by proteolytic digestion. It is interesting to note the $5 \mathrm{~A} 5$ and $7 \mathrm{~B} 2 \mathrm{mAbs}$ exhibited a similar IIF staining pattern characterised by intense staining at the nuclear margin, which was not a feature of the remaining $6 \mathrm{mAbs}$ characterised.

The $4 \mathrm{H} 1 \mathrm{mAb}$ produced a positive immunoblotting reaction with a $53 \mathrm{kDa}$ protein found in gradientpurified virus and in infected cells. On the basis that this protein is larger than the $47 \mathrm{kDa}$ SPDV E2, which was shown by immunoblotting using an anti-SDV E2 rabbit antiserum, it is concluded that $\mathrm{mAb} 4 \mathrm{H} 1$ is probably specific to the E1 glycoprotein. So far, we have been unable to directly determine the protein specificity of the other SPDV-specific mAbs. Although earlier radioimmunoprecipitation (RIPA) experiments showed that the 2D9 and 5D3 mAbs reacted specifically with a 50 to $55 \mathrm{kDa}$ protein (Welsh et al. 2000), more recent RIPA attempts with these and the remaining mAbs have failed to clearly identify individual proteins. Major reasons for the difficulties encountered with RIPA are the slow growth cycle of SPDV and its failure to shut off host protein synthesis, both of which result in poor incorporation of radiolabel into SPDV proteins. 
The abilities of the SPDV-specific mAbs to function as capture or detector reagents in ELISA tests have been investigated. Our results showed that a sandwich ELISA, in which mAb 2D9, adsorbed to the plate, is used for capture and biotinylated mAb 7A2 is used for detection, provided a method for detecting SPDV antigen. This reactive antigen was considered to be a virus structural protein or protein complex, since, following OG treatment, it was detectable in those sucrose gradient fractions that were shown by the immunodot assay to contain peak amounts of virus (Fig. 3). This ELISA, which had the ability to detect virus antigen present in lysates of cells at Day 3 p.i., may find application in estimating antigenic mass in vaccine production programmes or in diagnosis for the direct detection of antigen in tissue homogenates.

In conclusion, we believe that the SPDV-specific mAbs produced in this study will be useful for elucidating the pathogenesis of SPDV and developing much needed diagnostic tests. Moreover, the genetic similarity between SPDV and SDV makes it likely that these antibodies will also be useful in SDV studies.

Acknowledgements. This work was funded by Intervet-International, Boxmeer, The Netherlands. We would like to thank D. Pollock for his expertise in mouse monoclonal antibody production and C. Mason for the photography and image preparation.

\section{LITERATURE CITED}

Christie KE, Fyrand K, Holtet L, Rowley HM (1998) Isolation of pancreas disease virus from farmed Atlantic salmon, Salmo salar L., in Norway. J Fish Dis 21:391-394

Kent ML, Elston RA (1987) Pancreas disease in pen reared Atlantic salmon in North America. Bull Eur Assoc Fish

Editorial responsibility: Jo-Ann Leong,

Corvallis, Oregon, USA
Pathol 7:29-31

Laemmli UK (1970) Cleavage of structural proteins during the assembly of the head of bacteriophage T4. Nature 227: 680-685

McHugh PH, Mackie DP, McNulty MS, McFerran JB (1988) Production of monoclonal antibodies to bovine virus diarrhoea virus and their reactivity with selected pestivirus isolates. J Vet Med 35:207-213

McNulty MS, Allan GM (1984) Application of immunofluorescence in veterinary viral diagnosis. In: McNulty MS, McFerran JB (eds) Recent advances in virus diagnosis. Martinus Nijhoff, The Hague, p 15-26

Munro ALS, Ellis AE, McVicar AH, McLay HA (1984) An exocrine pancreas disease of farmed Atlantic salmon in Scotland. Helgolr Wiss Meeresunters Mar Invest 37: 571-586

Nelson RT, McLoughlin MF, Rowley HM, Platten MA, McCormick JI (1995) Isolation of a toga-like virus from farmed Atlantic salmon, Salmo salar, with pancreas disease. Dis Aquat Org 22:25-32

Poppe T, Rimstad E, Hyllseth B (1989) Pancreas disease in Atlantic salmon Salmo salar post smolts infected with infectious pancreatic necrosis virus (IPNV). Bull Eur Assoc Fish Pathol 9:83-85

Rowley HM, Doherty CE, McLoughlin MF, Welsh MD (1998) Isolation of salmon pancreas disease virus (SPDV) from farmed Atlantic salmon, Salmo salar L., in Scotland. J Fish Dis 21:469-471

Villoing S, Béarzotti M, Chilmonczyk S, Castric J, Brémont M (2000) Rainbow trout sleeping disease virus is an atypical alphavirus. J Virol 74:173-183

Welsh M, Weston J, Borghmans BJ, Mackie D, Rowley H, Nelson R, McLoughlin MF, Todd D (2000) Biochemical characterization of salmon pancreas disease virus. J Gen Virol 81:813-820

Weston JH, Welsh MD, McLoughlin MF, Todd D (1999) Salmon pancreas disease virus, an alphavirus infecting farmed Atlantic salmon, Salmo salar L. Virology 256: 188-195

Wheatley SB (1994) Epidemiological investigations of Atlantic salmon production using a computerised database system. PhD thesis, The Queen's University of Belfast

Submitted: November 24, 2000; Accepted: February 26, 2001 Proofs received from author(s): August 14, 2001 